\title{
Effects on Using Tutoring Application in Integration with Self-Directed Learning to Improve Statistical Analysis Skills
}

\author{
Sawanan Dangprasert
}

King Mongkut’s University of Technology North Bangkok, Bangkok, Thailand

\begin{abstract}
The purposes of this study were (1) to develop the tutoring application integrated with selfdirected learning to improve statistical analysis skills; (2) to compare the learners' pretest and posttest taken from their learning achievements; (3) to compare the learners' pretest and posttest taken from their statistical analysis skills; (4) to investigate the correlations of statistical analysis skills and learning achievements, and (5) to investigate the correlations of statistical analysis skills and the frequency of using this application. The research methodology divided into 2 major phases included Phase 1: The development of tutoring application integrated with self-directed learning to improve learners' statistical analysis skills, and Phase 2; The investigation of using the tutoring application. The data were statistically analyzed through using mean, t-test, and Pearson's correlation coefficient. The findings of the study revealed that the learners' scores of their posttest with its significant difference of .01 , according to the comparison of learners' statistical analysis skills, were higher than that of their pretest.
\end{abstract}

Keywords - tutoring application, self-directed learning, statistical analysis skills

\section{Introduction}

From the nature of teaching and learning at present,

DOI: $10.18421 /$ TEM101-08

https://doi.org/10.18421/TEM101-08

Corresponding author: Sawanan Dangprasert,

King Mongkut's University of Technology North Bangkok.

Email: sawanan.d@fte.kmutnb.ac.th

Received: 31 August 2020.

Revised: 10 December 2020.

Accepted: 18 December 2020.

Published: 27 February 2021.

(c))BY-NC-ND (C) 2021 Sawanan Dangprasert; published by UIKTEN. This work is licensed under the Creative Commons Attribution-NonCommercial-NoDerivs 4.0 License.

The article is published with Open Access at www.temjournal.com it is still not possible to fully meet the goals of learning. Currently, a variety of learners with their different ability levels, and the large numbers of students, as well as such a different student's individual learning management all resulted in the learners' reduction of statistical analysis skills. In terms of the limited length of study time, students were all required to search for additional knowledge outside the classroom.

The tutoring teaching system together with its qualification directly affected effective instructional management. In particular, artificial intelligence (AI) helped manage the system to be used as a substitute for books or classroom management. [1] In other words, the learners' contents together with the design of learning media were all supported for practices in quizzes, and exercises; moreover, it was sometimes used as a homework assistant. However, these media were often an integral part of existing teaching and learning. For research and development of intelligent tutoring teaching systems, at present there was a tendency towards learning in practice content which would automatically present the missing knowledge and skill training of the learners. Also, modern learning theories focused on the role of learners, with emphasis on practice and feedbacks during learning. [2] Another learning management process that can encourage learners to develop various skills is selfdirected learning because the main aim of this learning were to practice learners' statistical analysis skills; to train students' final decision-making together with problem-solving skills, as well as own lesson plans [3].

In addition to this learning, setting goals in their studies, creating lesson plans, seeking indigenous information resources and instructional media were all needed for this self-directed learning. Therefore, new technologies and innovations were all implemented for learners' learning development taken from other different information technological resources [4] occurring widely in modern times. In order to be beneficial for both instructors and learners, however, the effectiveness of tutoring application together with self-directed learning to improving the learners' statistical analysis skills should be investigated for the enhancement of learners' different skills on all educational levels. 


\section{Review of the Literature}

\subsection{Tutoring Application}

"Tutoring application" refers to a strategy that encourages learners' additional knowledge and skills obtained from evaluating learners' knowledge and appropriate tutoring contents transferred from instructors' pedagogical techniques.

The purpose of Intelligent Tutoring systems is to use the knowledge in a certain domain, knowledge of the students and teaching strategies for flexible individualized learning.

\subsection{Self - Directed Learning}

Self-directed learning was one of the methods used in higher education teaching, and the main aim of this approach was to offer students' educational opportunities continuously. Even if students' graduation lasted, it was considered to be continuous lifelong-learning development. Furthermore, it was a learning in which learners were responsible for planning, conducting, as well as evaluating the progress of their self-study. It was also the manner in which all learners existed while in a learning situation. Also, learners were able to transfer their learning and skills from learning from one situation to another [5].

Self-directed learning that was a process in which learners analyzed their own learning needs, together with their study goals, seeking supports for knowledge sources, educational media used in learning, and self-learning evaluation. However, learners might get support from others or might not. According to setting up learners' behaviors, it was stated that self-directed learning was a concept based on anthropological theory, which was involved in independence, and self-esteem of human beings. It was also said that all human beings were born with goodness, independence, self-esteem, and selfultimate potentiality, as well as their selfresponsibility.

\subsection{Teaching Strategies}

Teaching strategies refer to the sequence of steps focused on topics, tutoring teaching styles, the model of presentation on tutoring teaching topics, teaching materials, and examples of different exercises based on the learners' different required characteristics that are involved in the module of instructional management through using the tutoring application integrated with self-directed learning to enhance the learners' individual learning on their statistical analysis skills [6].

\subsection{User Experience Design}

User Experience or commonly referred to as UX is a person's perception and response resulting from the use of the product, a definition by UX design professionals [7]. User Experience is how you feel about each interaction you are facing with what lies ahead and when you use it. UX is dynamic, context dependent, and subjective [8].

\section{Research Objectives}

The objectives of this research were:

To develop the tutoring application integrated with self-directed learning to improve learners' statistical analysis skills;

To compare the learners' pretest and posttest taken from their learning achievements;

To compare the learners' pretest and posttest taken from their statistical analysis skills;

To investigate the correlations of statistical analysis skills and learning achievements, and

To investigate the correlations of statistical analysis skills and the frequency of using this application.

\section{Scope of Study}

\subsection{Population and Sample}

The researcher conducted an experiment with 11 graduate students of Technological Education Program, Education Technology and Information Science Department, Faculty of Technical Education, King Mongkut's University of Technology North Bangkok and all were selected by the purposive sampling technique. These included six master's degree students enrolling in the courses "Educational Statistic", five graduate students of the doctoral degree enrolled in the course "Advanced Statistics for Research".

\subsection{Variables Used for the Study}

The research variables comprised:

Independent variable: The learners' tutoring application integrated with self-directed learning to improve their statistical analysis skills

Dependent variables:

1) Learning achievements

2) Learner's statistical analysis skills

3) Correlations of learners' statistical analysis skills and their learning achievements

4) Correlations of statistical analysis skills and the frequency of using the tutoring application. 


\subsection{Contents}

Contents used for this study included the application of SPSS package program together with hypothesis analysis, variance analysis, multi-variance analysis, co-variance analysis, the analysis of correlations and regression, discriminant analysis, linear analysis, as well as factor analysis.

\subsection{Time}

This study was conducted during the $1^{\text {st }}$ semester of the 2019 academic year, and 15 weeks were spent for its research methodology.

\section{Research Methodology}

The research methodology divided into two major phases was as follows.

In the $1^{\text {st }}$ phase, related to the development of tutoring application integrated with self-directed learning to improve the learners' statistical analysis skills, information about the development of instructional applications in relations to the principle with other components, conceptual framework, drafted model of instructional model for learners' statistical analysis skills were all reviewed and analyzed. In addition, the presentation of course units together with the creation of exercises and aptitude tests, as well as reports on the learners' use of tutoring application encompasses four modules: 1) knowledge-based module; 2) student module; 3) pedagogical module, and 4) UX design module. The functions of such an element can be all explained as follows.

1) Knowledge-based module: It is an essential component of the application in integrations with artificial intelligence (AI) - based knowledge, which responds to learners' behaviors in realtime manners using its knowledge-based module designed for creating problems, as well as assigning learners' appropriate tasks. Not only are interpretations through questions perceived, but comparisons between expected learners' behaviors and actual learners' behaviors are also identified in terms of learners' knowledge evaluation, learning status, and their requirements for learning models. In order to provide databases on learners' instructional media, as well as to be testified with this module, however, it can be contributed for sharing instructional resources, which are sorted into two major parts: knowledge organization (KO) and knowledge repository (KR).

2) Student module: It is a core component of the application that functions with both the studentbased module and the knowledge-based module served for establishing learners' prototypical models. Besides, this model cited above is designed to provide information about teaching modules related to learners' privacy, pedagogical adjustments, as well as automatic pedagogical and learning strategy adjustments. In this regard, this module is also designed to accumulate learners' databases in terms of their learning abilities, effectiveness of academic performance, learning achievement progress, learning styles, as well as the learners' educational backgrounds and different test results. As a result, these information are all obtained from learning activities found in the student system.

3) Pedagogical module: The main function of this module emphasizes learners' effective instructional management together with their well-organized classroom management, learners' counseling services for different learning activities, working descriptions, approaches and reasons on learners' helps, appropriate instructional materials, as well as the learners' monitoring and evaluation of learning activities. In fact, this module is obtained from smart pedagogical approaches and learning strategies based on the implementation of learner's selfdirected learning so that this application's realtime instructional management outputs will be automatically proceeded; moreover, it is a central device that functions as a tutorial program relatively connected with other different modules in order to provide learners' self-directed learning-based well-prepared learning contents.

4) UX design module: The design of this module presents learning media, test results, and learners' learning evaluation involved in the learners' interacting process. It mainly focuses on collecting data and feedbacks of students and teachers in order to re-upgrade the UX design module application. Thus, this easy-to-access, convenient, and accurate application integrated with its self-directed learning is designed to improve the learners' statistical analysis skills because of the learners' more concentration and satisfactions on their use of learning application, as well as their effective instructional management in integrations with pedagogical modules. 


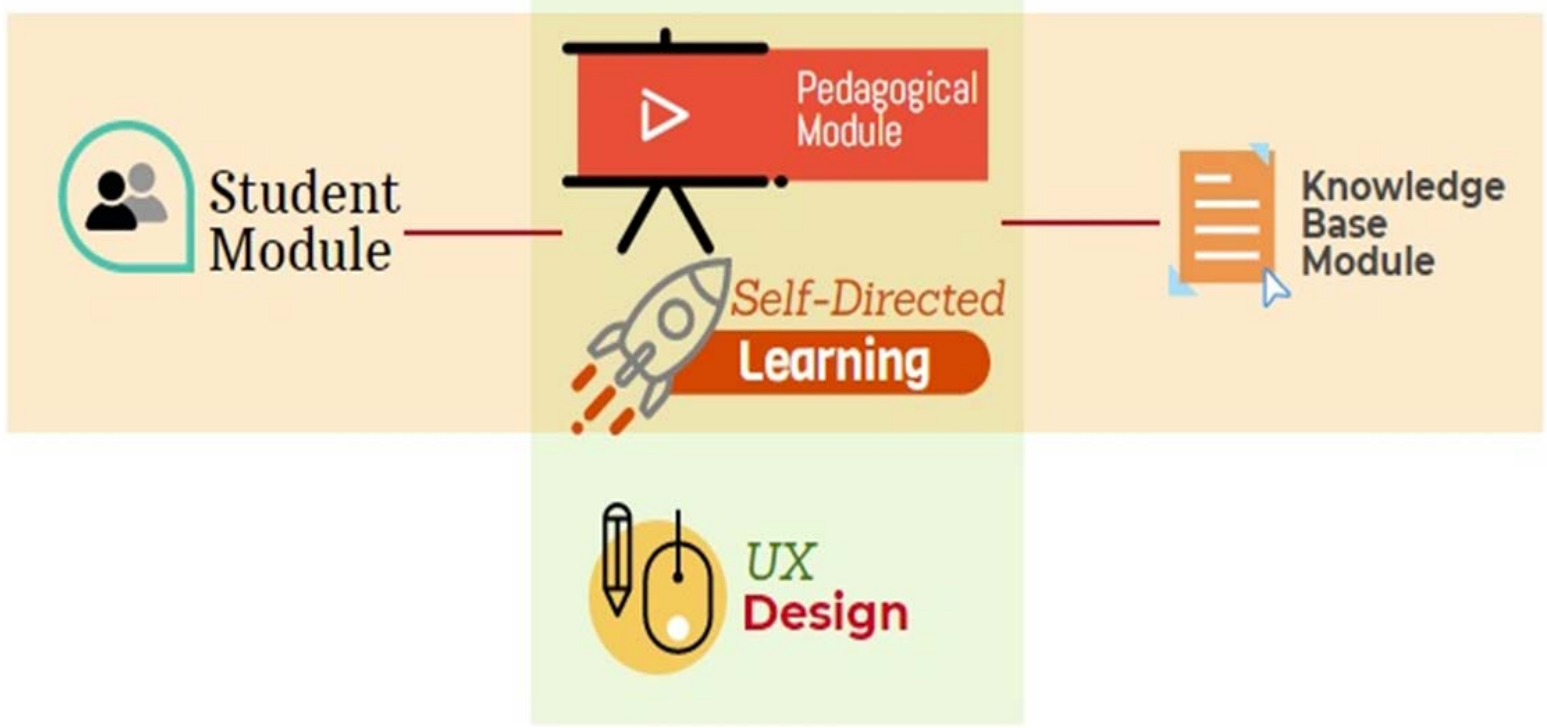

Figure 1. Components of tutoring application integrated with self-directed learning to improve learners' statistical analysis skills

Next, the effectiveness of tutoring application was evaluated by educational experts, and the approved evaluation checklist was finally validated by 7 major information technology-related experts.

In the $2^{\text {nd }}$ phase, related to the investigation of tutoring application outcomes, one-group experimental research was conducted for the learners' pretest and posttest obtain from the analysis of statistical analysis skills and learning achievements.

\section{Research Tools used for this Study}

1) 15-week lesson plans together with its worksheets, course contents, course description, objectives, and learning resources were all provided; moreover, learner's learning evaluation was informed.

2) In terms of the parallel form-oriented learning achievement, the structure of test items based on 9 learning units was set up for each learning unit's objectives. In other words, test items were then validated with using the index of item objective congruence (IOC), difficulty (p), and discrimination $(r)$.

3) The parallel form-oriented aptitude test on learner's statistical analysis skills was validated with using the index of item objective congruence (IOC).

\section{Data Collection}

During the $1^{\text {st }}$ semester of the 2019 academic year, information about learners' regulations of instructional management were firstly informed in

terms of the orientation session. Subsequently, the tutoring application used for improving the learners' statistical analysis skills was tried out, and a pretest was testified for the learners' learning achievements. After that, the learners' various learning activities were implemented for each learning period in order to facilitate the instructors' counseling services and follow-up on their learners' learning management inside and outside the classroom. Finally, a learning achievement test on learner's statistical analysis skills and their posttest were both testified for comparing the learners' scores.

\section{Data Analysis}

1) Differences between the learners' average scores of their pretest and posttest on learning achievements were all compared with t-test for dependent samples.

2) Differences between the learners' average scores of their pretest and posttest on their statistical analysis skills were all compared with t-test for dependent samples.

3) Correlations of learners' statistical analysis skills and learning achievements were analyzed using Pearson's correlation coefficient.

4) Correlations of statistical analysis skills and the frequency of using the tutoring application were analyzed using Pearson's correlation coefficient. 


\section{Summary}

The development of tutoring application integrated with self-directed learning to improve the learners' statistical analysis skills was classified into three major characteristics: 1) The presentation of the theoretical served for such a learner's level; 2) The abilities of controlling learners' selection of required topics, and 3) The abilities of selecting instructional media served for learners' interests. In other words, the learners' three required qualifications were detailed as follows. In the $1^{\text {st }}$ part related to learner ability, the learners' weakness on their statistical analysis skills was evaluated.
In the $2^{\text {nd }}$ part related to learner profiles, learner's individual information and databases on controlling the accessibility of tutoring application were all recorded. In the $3^{\text {rd }}$ part on learner backgrounds, information recorded for the accessibility of tutoring application included its learning evaluation, learning progression, as well as the length of testing used for each test question.

According to the comparison of learners' learning achievements obtained from their pretest and posttest, it showed that their posttest with its significant difference of .01 was higher than that of their pretest as illustrated in Table 1.

Table 1. A comparison of learners' learning achievements obtained from their pretest and posttest

\begin{tabular}{|c|c|c|c|c|c|c|c|c|c|}
\hline & & \multirow[t]{2}{*}{ Mean } & \multirow[t]{2}{*}{$\begin{array}{c}\text { Std. } \\
\text { Deviation }\end{array}$} & \multirow{2}{*}{$\begin{array}{l}\text { Std. } \\
\text { Error } \\
\text { Mean }\end{array}$} & \multicolumn{2}{|c|}{$\begin{array}{l}99 \% \text { Confidence } \\
\text { Interval of the } \\
\text { Difference }\end{array}$} & \multirow[t]{2}{*}{$\mathrm{t}$} & \multirow[t]{2}{*}{ df } & \multirow[t]{2}{*}{ Sig (2-tailed) } \\
\hline & & & & & Lower & Upper & & & \\
\hline Score & Pretest - Posttest & -29.364 & 2.838 & .856 & -32.076 & -26.652 & -34.32 & 10 & .000 \\
\hline
\end{tabular}

Table 2. A comparison of learners' statistical analysis skills obtained from their pretest and posttest.

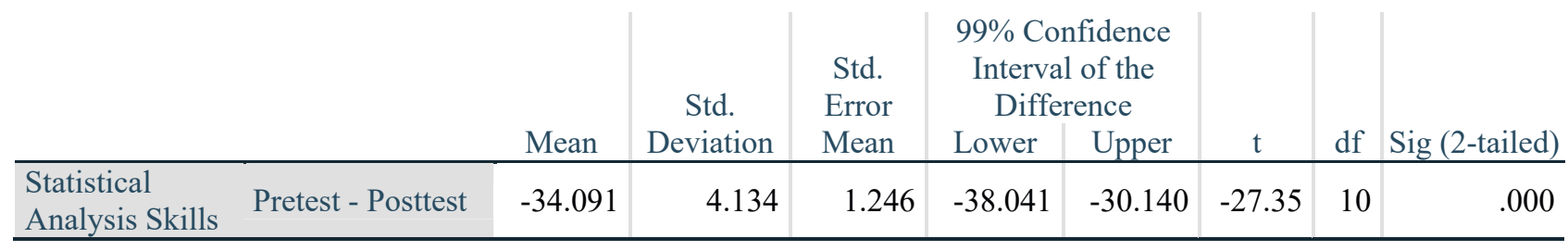

From Table 2., it is showed that the scores of learners' posttest on their statistical analysis skills, with its significant difference of .01 , were higher than that of their pretest.

Table 3. Results on correlations of learners' statistical analysis skills and learning achievements

\begin{tabular}{|c|c|c|c|}
\hline & & $\begin{array}{l}\text { earning } \\
\text { ievements }\end{array}$ & $\begin{array}{c}\text { Statistical } \\
\text { Analysis } \\
\text { Skills }\end{array}$ \\
\hline \multirow{3}{*}{$\begin{array}{l}\text { Learning } \\
\text { Achievements }\end{array}$} & $\begin{array}{l}\text { Pearson } \\
\text { Correlation }\end{array}$ & 1 & $.911^{* *}$ \\
\hline & Sig. (2-tailed) & & .000 \\
\hline & $\mathrm{N}$ & 11 & 11 \\
\hline \multirow{3}{*}{$\begin{array}{l}\text { Statistical } \\
\text { Analysis Skills }\end{array}$} & $\begin{array}{l}\text { Pearson } \\
\text { Correlation }\end{array}$ & $.911^{* *}$ & 1 \\
\hline & Sig.(2-tailed) & .000 & \\
\hline & $\mathrm{N}$ & 11 & 11 \\
\hline
\end{tabular}

**. Correlation is significant at the 0.01 level (2-tailed).

From Table 3., it is showed that the coefficient of correlations of the learners' learning achievements and statistical analysis skills was significant different at .01, and the learners' statistical analysis skills all resulted in their better learning achievements.
Table 4. The results of the study of the relationship between statistical analysis skills and application access frequencies

\begin{tabular}{llc|c} 
& & \multicolumn{1}{c}{$\begin{array}{c}\text { Statistical } \\
\text { Analysis } \\
\text { Skills }\end{array}$} & $\begin{array}{c}\text { Application } \\
\text { access } \\
\text { frequencies }\end{array}$ \\
\hline $\begin{array}{l}\text { Statistical } \\
\text { Analysis } \\
\text { Skills }\end{array}$ & Pearson Correlation & 1 & $.901^{* *}$ \\
\cline { 2 - 4 } & Sig. (2-tailed) & & .000 \\
\hline $\begin{array}{l}\text { Application } \\
\text { access } \\
\text { frequencies }\end{array}$ & Pearson Correlation & $.901^{* *}$ & 11 \\
\cline { 2 - 4 } & Sig. (2-tailed) & .000 & 1 \\
\hline
\end{tabular}

**. Correlation is significant at the 0.01 level (2-tailed)

From Table 4., it is showed that the coefficients of the correlations of statistical analysis skills and application access frequencies with its significant difference of .01 were mostly found; moreover, the learners' frequent use of their accessibility of tutoring applications directly affected their better improvement for statistical analysis skills. 


\section{Conclusion}

As compared to the learner's learning achievements, it is showed that the learners' scores of their posttest were higher than that of their pretest. The results of the research showed that the learners who learned by using their tutoring application integrated with self-directed learning to improve their statistical analysis skills directly led to their better abilities of statistical analysis skills. Therefore, it was considered a good way of learning that helped encourage them to learn more efficiently. In addition, it also helped learners learn and achieve content objectives, with emphasis on the speed of learning in each individual set up by instructors or the class. [9] Also, modern information technologies were all facilitated for creating interesting learning atmospheres that would result in the learners' amusement and better understanding of each content. With references to the study of [10], it was stated that the learners' scores of their posttest were higher than that of their pretest obtained from their learning achievements. It was also consistent with [11] research where learners were able to create scientific knowledge, which resulted in a higher average student achievement score than before learning. According to the research results in line with the law of exercise, the learner's behavior in relations to his/her frequent action and constant improvements resulted in organizing teaching and learning activities, stimulating the learners' learning experiences, preparing the learners to be ready, as well as participating in their motivation for selflearning and teaching methods related to both learners' knowledge and skills.

In order to effectively manage the learners' implementation for tutoring application integrated with self-directed learning to improve their statistical analysis skills, important issues were detailed as follows. Both the learners' and instructors' instructional management in relations to related documents, instructional media, teaching approaches, lesson plans, the understandings of computer with its accessories, as well as tools used for instructional management should be well-prepared for their students' learning motivation. However, the wellplanned instructional management obtained from instructors, learners, or learning processes directly affected its learning goals provided.

In terms of the learners' effective instructional management, the learners' various learning activities on their statistical analysis skills, with emphasis on its course objectives of each activity, should be provided for the learners' interests, learning motivation, and their learning requirements.
In terms of the learners' self-directed learning, the learners' control, follow-up, and examination were vital because the learners' autonomous learning resulted from outside classroom activities. As a result, standards or indicators related to learners' course contents taken from lesson plans should be set up before their co-learning was supported for the learners' self-responsibilities of their task assignments, as well as their better learning qualifications.

\section{References}

[1]. Alpert, S. R., Singley, M. K., \& Fairweather, P. G. (1999). Deploying intelligent tutors on the web: An architecture and an example. International Journal of Artificial Intelligence in Education, 10(2), 183-197.

[2]. Kirschner, P. A., Sweller, J., \& Clark, R. E. (2006). Why minimal guidance during instruction does not work: An analysis of the failure of constructivist, discovery, problem-based, experiential, and inquirybased teaching. Educational psychologist, 41(2), 7586.

[3]. F. Dixon. (1992). A Guide for Learners and Teacher. Journal of Education, 2(2), 17-19.

[4]. M. Knowles. (1975). Self - Directed Learning. Journal of Education, 9(5), 14-18.

[5]. Hiemstra, R. (1994). Self-directed learning. In T. Husen and T. N. Postlethwaite. The International Encyclopedia of Education (second edition). Oxford: Pergamon Press.

[6]. Dağ, F., \& Erkan, K. (2003). Realizing of optimal curriculum sequences for a web based general purpose intelligent tutoring system. In Proceedings Turkish Symposium of Artificial Intelligence and Neural Networks (Vol. 1, pp. 1-3).

[7]. Law, E. L. C., Van Schaik, P., \& Roto, V. (2014). Attitudes towards user experience (UX) measurement. International Journal of HumanComputer Studies, 72(6), 526-541.

[8]. Law, E. L. C., Roto, V., Hassenzahl, M., Vermeeren, A. P., \& Kort, J. (2009, April). Understanding, scoping and defining user experience: a survey approach. In Proceedings of the SIGCHI conference on human factors in computing systems (pp. 719-728). doi:10.1145/1518701.1518813

[9]. Tullis, J. G., \& Benjamin, A. S. (2011). On the effectiveness of self-paced learning. Journal of memory and language, 64(2), 109-118. doi:10.1016/j.jml.2010.11.002.

[10]. Lai, C., \& Zheng, D. (2018). Self-directed use of mobile devices for language learning beyond the classroom. ReCALL, 30(3), 299-318.

[11]. Chiang, Y. H., \& Wang, H. C. (2015). Effects of the in-flipped classroom on the learning environment of database engineering. The International journal of engineering education, 31(2), 454-460. 